\title{
A Comparison of Microwave-Assisted Heating with Conventional Heating of Sweet Potato (Ipomoea batatas): Analysis of Monosaccharides and Disaccharides
}

\author{
Toratane Munegumi*, Akito Goto, Yoshihide Nakamura \\ Naruto University of Education, Tokushima, Japan \\ Email: ^tmunegumi@naruto-u.ac.jp
}

How to cite this paper: Munegumi, T., Goto, A. and Nakamura, Y. (2019) A Comparison of Microwave-Assisted Heating with Conventional Heating of Sweet Potato (Ipomoea batatas): Analysis of Monosaccharides and Disaccharides. Food and Nutrition Sciences, 10, 315-324.

https://doi.org/10.4236/fns.2019.103024

Received: February 23, 2019

Accepted: March 23, 2019

Published: March 26, 2019

Copyright $\odot 2019$ by author(s) and Scientific Research Publishing Inc. This work is licensed under the Creative Commons Attribution International License (CC BY 4.0).

http://creativecommons.org/licenses/by/4.0/

\begin{abstract}
Microwave-assisted heating has been recently used for extracting nutrient components from food materials. The technique sometimes invokes reactions from nutrient compounds during microwave-irradiation because it activates water molecules to reach a high temperature. The microwave-irradiation produced $5.3 \mathrm{~g}$ maltose per $100 \mathrm{~g}$ sweat potatoes in $30 \mathrm{~s}$, which was faster than conventional heating ( $3.9 \mathrm{~g}$ maltose per $100 \mathrm{~g}$ in $300 \mathrm{~s}$ ). Fructose level increased with the longer reaction time under microwave-irradiation (from $1.33 \mathrm{~g}$ to $1.65 \mathrm{~g}$ in 120s), but decreased with a longer reaction time under conventional heating (from $0.99 \mathrm{~g}$ to $0.83 \mathrm{~g}$ in $1200 \mathrm{~s}$ ). This study demonstrates the differences in the reactions and products between microwave-irradiation and conventional heating.
\end{abstract}

\section{Keywords}

Microwave-Assisted Heating, Sweat Potato, Saccharides, HPLC, Amino Column

\section{Introduction}

Crop plants have been an indispensable part of human life for ages. Ever since ancient time, fruits, seeds, even roots and branches have been used to meet personal and social needs such as food, medicine, and the beautification of the environment [1] [2] [3] [4] [5]. The crop plants sweet potato is known as an energy source [6] [7], with starch as the main ingredient (20.1\%). Raw root sweet potato usually contains monosaccharides: glucose and fructose as well as disaccharide sucrose [7] [8]. However, the heating of sweet potatoes yields maltose, which is 
the main saccharide that contributes to the sweetness of baked sweet potatoes [6] [9]. Starch is hydrolyzed to maltose by the action of the enzymes [8] [9] [10] [11] [12]: $\alpha$-amylase (EC 3.2.1.1) [13] and $\beta$-amylase (EC 3.2.1.2) [14] [15]. Invertase (EC 3.2.1.26) [16] [17] [18] [19] [20], maltase: ( $\alpha$-glucosidase, EC 3.2.1.20) [19] [21], and sucrose synthase (EC 2.4.1.13) [21] have been also known as the other enzymes involved with the reactions of saccharides in sweet potatoes. The concentration of $\beta$-amylase is higher than those of $\alpha$-amylase and enzymes in the roots [15], whereas $\beta$-amylase in storage roots does not activate. Because $\beta$-amylase hydrolyzes starch to maltose faster at the optimum temperature, cooking for several minutes longer at this temperature increases the sweetness of potatoes. Although microwave-assisted heating gives a higher temperature in fewer seconds, heated sweet potatoes have less sweetness because of the lower yield of maltose. Microwave-irradiation induces different chemical reactions than conventional heating [22].

Studies related to microwave-assisted organic syntheses have been reported [22] [23]. Microwave-assisted reactions have been applied to the chemistry of carbohydrates [23] [24] [25] [26]. Richard and Paquot [25] classify the microwave-assisted reactions of saccharides into two categories as follows: the reactions involving hydroxyl groups for the production of novel entities, and the dehydration reactions leading to the formation of 5-(hydroxymethyl)furfural [27] and related platform molecules [25]. It has been reported that, under microwave-irradiation, thermal hydrolysis of a disaccharide (maltose) is accelerated [28], and the decomposition of monosaccharides to 5-(hydroxymethyl)furfural or furfural takes place [29] [30]. However, not many research papers on the isomerization of saccharides have been published [23] [25] [30] [31] [32]. This report describes comparison of microwave-assisted heating with conventional heating of sweet potato (Ipomoea batatas), analyzing monosaccharides: glucose and fructose and disaccharides: maltose and sucrose in sweat potatoes under microwave-irradiation.

\section{Materials and Methods}

\subsection{Sample Preparation for Microwave-Irradiation and Conventional Heating}

A piece (about $15 \times 4 \mathrm{~cm}$ ) of sweet potato (Ipomoea batatas (L.) Lam, Koukei 14), so-called "Naruto Kintoki" was hollowed out with a cork borer (inner diameter: $1.9 \mathrm{~cm})$. A part $(10 \mathrm{~g})$ of columnar sweet potato left in the inside of the cork borer was removed into a glass tube $(6.3 \times 2.6 \phi \mathrm{cm})$, which was used for irradiation with a microwave generator. Similarly, a part (10 g) of columnar sweet potato obtained by using a cork borer (inner diameter: $1.4 \mathrm{~cm}$ ) was wrapped with an aluminum sheet. The wrapped sweet potato was put into a hole $(6.0 \times$ $1.5 \phi \mathrm{cm})$ of an aluminum brock set at $100^{\circ} \mathrm{C}$.

\subsection{Microwave-Irradiation}

A sweet potato samples in a glass vial set at the center of turning table was irra- 
diated with a kitchen microwave generator UMB-1736 (NEC, Tokyo, Japan).

\subsection{Heating with an Aluminum Heat Bath}

Heating samples of sweet potato was carried out with a MG-2200 aluminum heat bath (EYELA, Tokyo, Japan) set at $100^{\circ} \mathrm{C}$.

\subsection{Analysis of Samples}

Irradiated or heated samples were cooled to room temperature and suspended in $30 \mathrm{~mL}$ water. The resulting suspensions were separately mixed with a crusher, Labo Misler LM-PLUS (Osaka Chemical, Osaka, Japan) for $30 \mathrm{~s}$ and centrifuged at $13,370 \mathrm{rpm}(27,000 \mathrm{G})$ with a Beckman Coulter JA-17 fixed an angle rotor $(12.3 \mathrm{~cm})$ for $20 \mathrm{~min}$ at $0^{\circ} \mathrm{C}$. The supernatant fluid was filter with a membrane filter (MILLEX-PF $0.8 \mu \mathrm{m}$ ), and the filtrate was injected into a HPLC system (Shimadzu, Kyoto, Japan) which is composed of pump, LC-20TA; system controller, CBM-20A; UV-detector, RID-10A; auto-sampler, SIL-20A; column oven, CTO-20A. Sample solutions were automatically injected into an analytical column: $\mathrm{NH}_{2}$ P-50 4D $150 \mathrm{~mm} \times 4.6 \mathrm{~mm}$ (Showa Denko K. K., Tokyo, Japan) whose temperature was maintained at $40^{\circ} \mathrm{C}$. Analysis was carried out three times for each sample using an eluate: acetonitrile-water $(75-25(\mathrm{v} / \mathrm{v}))$ at a flow rate of $1.5 \mathrm{~mL} / \mathrm{min}$. The absorption of the eluted solution was continuously detected at $190 \mathrm{~nm}$. The averaged peak area $(\mu \mathrm{V} \cdot \mathrm{min})$ and the standard deviation for each peak were recorded. Each compound was determined using the relation between the peak area and the amount of the standard compound.

\section{Results and Discussion}

\subsection{Irradiation to Sweet Potatoes with a Microwave Generator}

Several power conditions were used for determining the appropriate conditions. Table 1 summarizes weight decrease of sweet potatoes after irradiation.

Table 1. Weight decrease of sweet potatoes after irradiation with different conditions.

\begin{tabular}{cccc}
\hline & \multicolumn{3}{c}{ Reaction conditions and weight decrease } \\
\cline { 2 - 4 } Power $(\mathrm{W})$ & 30 & $\begin{array}{r}\text { Temperature rise from } \\
\text { room temperature }\left({ }^{\circ} \mathrm{C}\right)\end{array}$ & Weight decrease $(\mathrm{mg})$ \\
\hline \multirow{2}{*}{120} & 60 & $\mathrm{a}$ & 5.8 \\
& 30 & $\mathrm{a}$ & 14.5 \\
280 & 60 & 52.1 & 34.1 \\
350 & 30 & 64.0 & 130.2 \\
& 60 & 63.1 & 45.4 \\
& 30 & 63.3 & 252.3 \\
500 & 60 & 63.5 & 131.9 \\
& 30 & 64.2 & 754.0 \\
600 & 60 & 64.4 & 444.3 \\
& 60 & 64.3 & 1240.9 \\
\hline
\end{tabular}

a. Temperature was not measured due to hard inside. 
The microwave generator was available to select electric power conditions $(120,280,350,500$, and $600 \mathrm{w})$ for irradiation. Softness and temperature inside were monitored after irradiation in each electric power conditions. The temperature inside became about 50 to 65 degree higher than room temperature except of $120 \mathrm{w}$. Electric power condition $350 \mathrm{w}$ was most suitable for monitoring temperature, because the sample after irradiation using $350 \mathrm{w}$ became whole soft. Figure 1 shows pictures just after microwave-irradiation.

\subsection{Analysis of Microwave-Irradiated Sweet Potatoes}

Sweet potato samples after microwave-irradiation were crushed and extracted water. The extracts were analyzed with HPLC as shown in Figure 2(a).

Similarly, the extracts from the reaction solution using aluminum heat bath at 100 degree were analyzed as shown in Figure 2(b). The chromatograms are compared with the extract (Figure 2(c)) from the sample of raw sweet potato. These saccharides were completely separated upon the baseline. There was linearity between the peak area and the mass of the injected each saccharide. Figure 3 shows the quantity changes of saccharides in $100 \mathrm{~g}$ of sweet potato samples after microwave-irradiation.

Reaction times for microwave-irradiation are very short like 30 to $120 \mathrm{sec}$, while reaction times for usual heating in an aluminum heat bath are longer like 5 to 20 min corresponding to 300 to $1200 \mathrm{sec}$. Compared with these reactions, there are some similarity to each other in quantities. Quantity of glucose was similar between microwave-irradiation and aluminum heat bath, and did not change much with the irradiation and heating. Sucrose decrease a little with the irradiation and heating. Maltose was not obtained at all under no-heating. It means raw sweet potatoes do not have maltose. The microwave-irradiation produced $5.3 \mathrm{~g}$ maltose per $100 \mathrm{~g}$ sweat potatoes in $30 \mathrm{~s}$, which was faster than conventional heating ( $3.9 \mathrm{~g}$ maltose per $100 \mathrm{~g}$ in $300 \mathrm{~s}$ ). Even short irradiation and heating fostered the formation of maltose, which may be caused by hydrolysis of starch by enzyme $\beta$-amylase. The observation consistent with the results was reported [12]. The level of maltose decreased with the proceeded reaction time under both reaction conditions.

Some different features can be observed between the different energy sources. Fructose level increased with the longer reaction time under microwave-irradiation (from $1.33 \mathrm{~g}$ to $1.65 \mathrm{~g}$ in $120 \mathrm{~s}$ ), but decreased with a longer reaction time under conventional heating (from $0.99 \mathrm{~g}$ to $0.83 \mathrm{~g}$ in $1200 \mathrm{~s}$ ). Heating in an aluminum

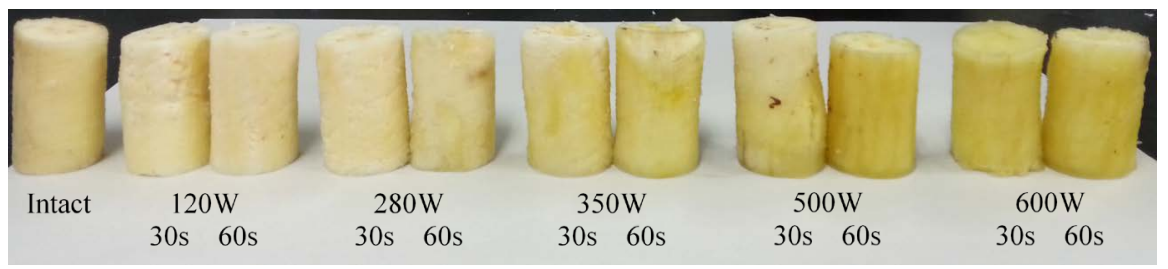

Figure 1. Sweet potato samples just after microwave-irradiation. 


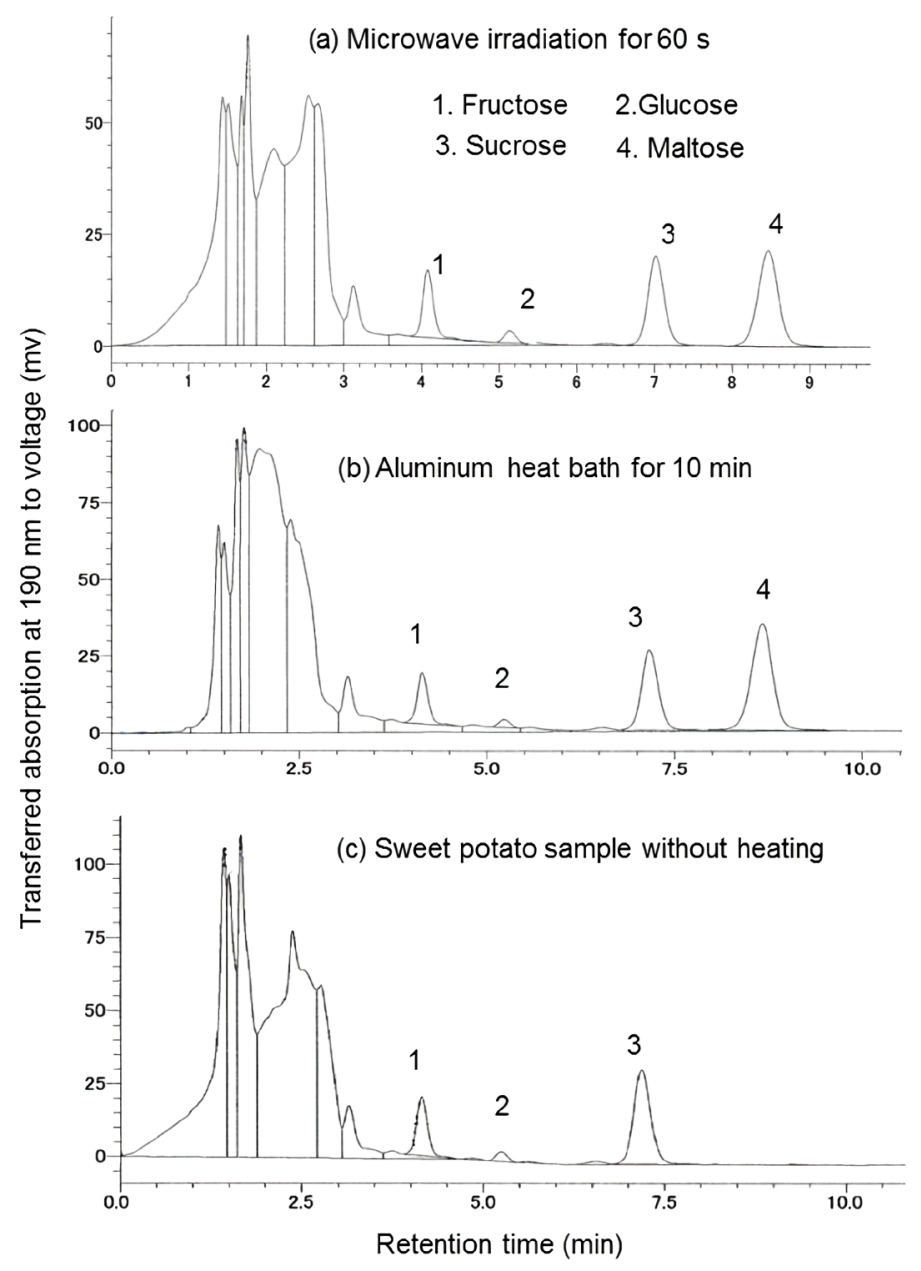

Figure 2. HPLC of an extracted solution from a microwave-irradiated sweet potato sample. Analytical conditions: column, $\mathrm{H}_{2} \mathrm{~N}-\mathrm{P}-504 \mathrm{D}(150 \mathrm{~mm} \times 4.6 \mathrm{~mm})$; eluate, acetonitrile-water $(3: 1(\mathrm{v} / \mathrm{v}))$; flow rate, $1.5 \mathrm{~mL} / \mathrm{min}$; detection, $\mathrm{UV}$ at $190 \mathrm{~nm}$.
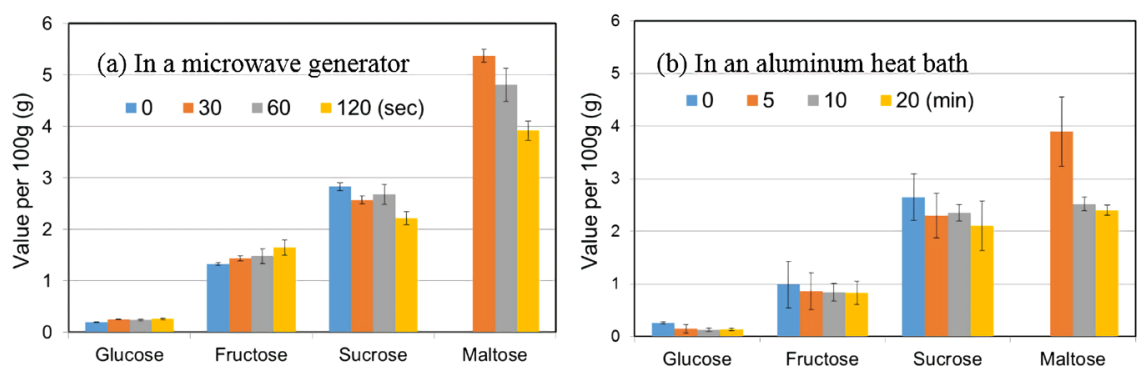

Figure 3. Detected main saccharides in sweet potato samples irradiated with a microwave generator (a) and heated an aluminum heat bath (b). The black lines in the center of data columns show the margin of error in the measurement.

heat bath showed the neither increase of glucose and fructose, although microwave-irradiation showed the increase of fructose. As mentioned above, microwave-irradiation facilitates different reactions from usual heating. One of authors has recently reported that glucose isomerizes to fructose under microwave-irradiation in the aqueous solutions [33]. The results suggest that glucose 
may isomerize in the gelled sweet potato by microwave-irradiation, because the sweet potato includes a little amount of water. Under microwave-irradiation [25] and at higher temperature on the conventional heating Fructose can be dehydrated to 5-hydroxymethyl-furfural, which is a toxic compound [34] [35].

Figure 4 shows a hypothetical reaction pathway, which explains the results shown in Figure 3.

As shown in Figure 4, $\alpha$-amylase hydrolyzes starch of sweet potato to maltose, which might be hydrolyzed two glucose molecules by maltase. Sucrose might be hydrolyzed to glucose and fructose by invertase. Glucose cannot isomerize to fructose by (A) conventional heating in an aluminum heat bath but can isomerize to fructose by (B) microwave-irradiation [32]. Fructose might be dehydrated to 5-(hydroxymethyl)furfural. However, since the peak (the retention time of standard sample: 1.85 min in Figure 5) overlaps with a bulk of peaks on the chromatogram of reaction mixtures, 5-(hydroxymethyl)furfural was not identified.

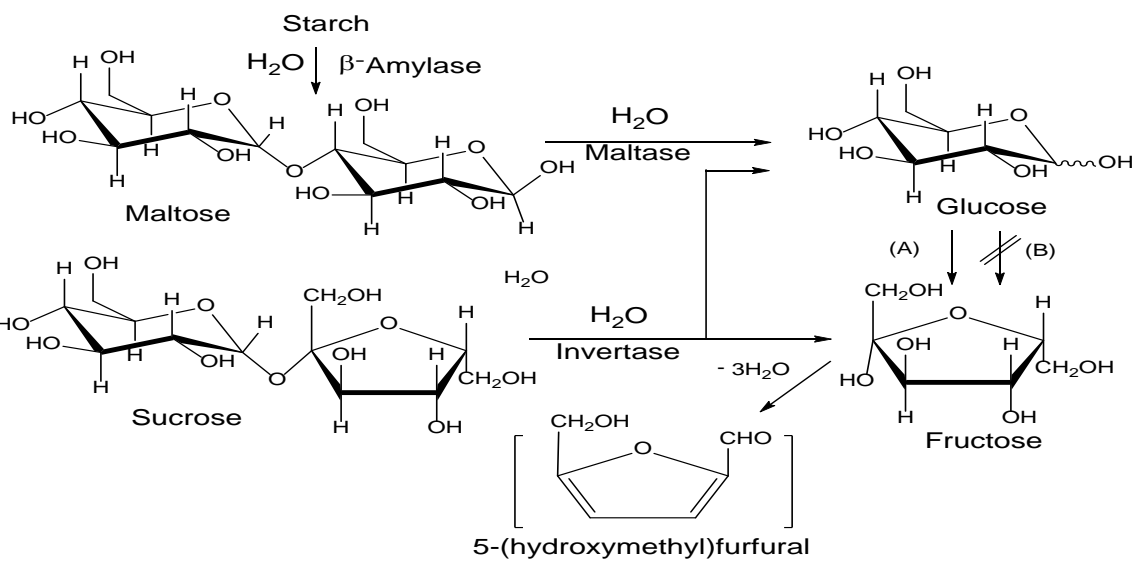

Figure 4. Hypothetical reaction pathway of saccharides in heated sweet potatoes by the microwave-irradiation (A) and the conventional heating in an aluminum heat bath (B).

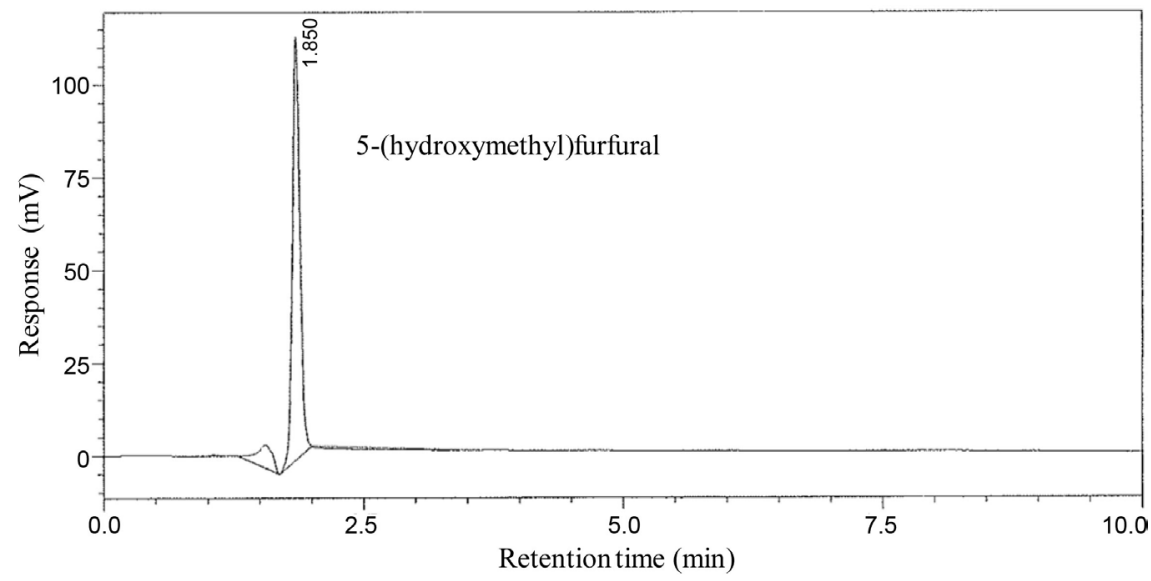

Figure 5. HPLC of standard 5-(hydroxymethyl)furfural. Analytical conditions: column, $\mathrm{H}_{2} \mathrm{~N}-\mathrm{P}-504 \mathrm{D}(150 \mathrm{~mm} \times 4.6 \mathrm{~mm})$; eluate, acetonitrile-water $(3: 1(\mathrm{v} / \mathrm{v}))$; flow rate, 1.5 $\mathrm{mL} / \mathrm{min}$; detection, $\mathrm{UV}$ at $190 \mathrm{~nm}$. 
Although Figure 4 may partly explain the reactions under microwave-irradiation, it cannot precisely explain the reactions in an aluminum heat bath. The decrease of glucose is inconsistent with the fact that glucose cannot change to fructose in the conventional heating [33]. If maltose hydrolyzed to glucose, glucose must have increased. Sucrose as well as glucose and maltose will decrease in the pathways different from Figure 4. Further research involving ingredients of sweet potatoes may clarify the reasonable mechanism. And analysis of 5-(hydroxylmethyl)furfural could be expected to support the decrease of fructose by heating in an aluminum heat bath.

\section{Conclusion}

This study demonstrated HPLC analysis of mono- and disaccharides in the reacted sweet potato samples by microwave-irradiation and conventional heating. HPLC using an amino column $\left(\mathrm{H}_{2} \mathrm{~N}-\mathrm{P}-504 \mathrm{D}\right)$ was effective for complete separation of glucose, fructose, maltose, and sucrose included in heated sweet potato samples. Fructose increased during microwave-irradiation to a sweet potato sample; it decreased during the conventional heating in an aluminum heat bath. The increase of fructose during microwave-irradiation to sweet potato samples is consistent with the results of microwave-irradiation to aqueous solutions of glucose. Since fructose increases in sweet potatoes during microwave-irradiation, the formation of 5-(hydroxymethyl)furfural may be focused on in the further investigation. The earlier reactions induced by microwave-irradiation and the conventional heating gave the increase of maltose, while further heating revealed the decrease of maltose.

\section{Acknowledgements}

The research was partly supported by the Discretionary Budget of the President of Naruto University of Education in 2012.

\section{Conflicts of Interest}

The authors declare no conflicts of interest regarding the publication of this paper.

\section{References}

[1] Ercisli, S. (2009) Apricot Culture in Turkey. Scientific Research and Essays, 4, 715-719.

[2] Erturk, Y., Ercisli, S., Haznedar, A. and Cakmakci, R. (2010) Effects of Plant Growth Promoting Rhizobacteria (PGPR) on Rooting and Root Growth of Kiwifruit (Actinidia deliciosa) Stem Cuttings. Biological Research, 43, 91-98. https://doi.org/10.4067/S0716-97602010000100011

[3] Canan, I., Gundogdu, M., Seday, U., Oluk, C.A., Karasahin, Z., Eroglu, E.C. and Yazici, E. (2016) Determination of Antioxidant, Total Phenolic, Total Carotenoid, Lycopene, Ascorbic Acid, and Sugar Contents of Citrus Species and Mandarin Hybrids. Turkish Journal of Agriculture and Forestry, 40, 894-899. 
https://doi.org/10.3906/tar-1606-83

[4] Hricova, A., Fejer, J., Libiakova, G., Szabova, M., Gazo, J. and Gajdosova, A. (2016) Characterization of Phenotypic and Nutritional Properties of Valuable Amaranthus cruentus L. Mutants. Turkish Journal of Agriculture and Forestry, 40, 761-771. https://doi.org/10.3906/tar-1511-31

[5] Yazici, K. and Sahin, A. (2016) Characterization of Pomegranate (Punica granatum L.) Hybrids and Their Potential Use in Further Breeding. Turkish Journal of Agriculture and Forestry, 40, 813-824. https://doi.org/10.3906/tar-1604-120

[6] Woolfe, J.A. (1992) Sweet Potato an Untapped Food Resource. Cambridge University Press, Cambridge, UK.

[7] Bradbury, J.H. and Holloway, W.D. (1988) Effect of Cooking on Nutrient Contents of Tropical Root Crops from the South Pacific. ACIAR Monograph Ser. No. 6, Canberra.

[8] Gore, H.C. (1923) Formation of Maltose in Sweet Potatoes on Cooking. Industrial \& Engineering Chemistry, 15, 938-940. https://doi.org/10.1021/ie50165a031

[9] Lai, Y.-C., Huang, C.-L. and Chan, C.-F. (2013) Studies of Sugar Composition and Starch Morphology of Baked Sweet Potatoes (Ipomoea Batatas (L.) Lam). Journal of Food Science and Technology, 50, 1193-1199. https://doi.org/10.1007/s13197-011-0453-6

[10] Balls, A.K., Walden, M.K. and Thompson, R.R. (1948) A Crystalline Beta-Amylase from Sweet Potatoes. Journal of Biological Chemistry, 173, 9-19. http://www.jbc.org/content/173/1/9.full.pdf + html

[11] Walter, J.R., Purcell, W.M. and Nelson, A.M. (1975) Effects of Amylolytic Enzymes on "Moistness" and Carbohydrate Changes of Baked Sweet Potato Cultivars. Journal of Food Science, 40, 793-796. https://doi.org/10.1111/j.1365-2621.1975.tb00558.x

[12] Roy, F. and Hedge, M.V. (1985) Rapid Method for Purification of Beta-Amylase from Ipomoea batatas. Journal of Chromatography, 324, 489-494. https://doi.org/10.1016/S0021-9673(01)81354-6

[13] Ikeyama, M. and Deobald, H.J. (1966) New Characteristic Alpha-Amylase in Sweet Potatoes. Journal of Agricultural and Food Chemistry, 14, 237-241. https://doi.org/10.1021/jf60145a011

[14] Uehara, K. and Mannen, S. (1979) Interaction of Sweet Potato $\alpha$-Amylase with Its Reaction Product, Maltose. Journal of Biochemistry, 85, 105-113. https://www.jstage.jst.go.jp/article/biochemistry1922/85/1/85_1_105/_pdf https://doi.org/10.1093/oxfordjournals.jbchem.a132299

[15] Takahata, Y., Noda, T. and Nagata, T. (1994) Amylase Stability and Starch Gelatinization during Heating on Varietal Differences in Maltose Content in Sweet Potatoes. Journal of Agricultural and Food Chemistry, 42, 2564-2569. https://doi.org/10.1021/jf00047a036

[16] Pressey, R. (1968) Invertase Inhibitors from Red Beet, Sugar Beet and Sweet Potato Roots. Plant Physiology, 43, 1430-1434. https://doi.org/10.1104/pp.43.9.1430

[17] Marshall, J.J. and Whelan, W.J. (1973) Removal of $\alpha$-Glucoside Impurity from Crystalline Sweet-Potato $\beta$-Amylase. Analytical Biochemistry, 52, 642-646. https://doi.org/10.1016/0003-2697(73)90073-0

[18] Matsushita, K. and Uratani, I. (1974) Change in Invertase Activity of Sweet Potato in Response to Wounding and Purification and Properties of Its Invertases. Plant Physiology, 54, 60-66. https://doi.org/10.1104/pp.54.1.60 
[19] Mineo, H., Nakazawa, T., Morikawa, N., Ishida, K., Ohmi, S., Machida, A., Noda, T., Fukushima, M. and Chiji, H. (2008) Feeding of Potato Starch Increases Maltose and Sucrose Activity Only in Duodenal Segment of the Small Intestine in Rats. Journal of Applied Glycoscience, 55, 203-209. https://doi.org/10.5458/jag.55.203

[20] Haung, G., Sheu, M., Chang, Y., Lu, T., Chang, H., Huang, S. and Lin, Y. (2008) Isolation and Characterisation of Invertase Inhibitor from Sweet Potato Storage Roots. Journal of the Science of Food and Agriculture, 88, 2615-2621. https://doi.org/10.1002/jsfa.3380

[21] Takahata, Y., Noda, T. and Sato, T. (1995) Changes in Carbohydrates and Enzyme Activities of Sweetpotato Lines during Storage. Journal of Agricultural and Food Chemistry, 43, 1923-1928. https://doi.org/10.1021/jf00055a031

[22] Herrero, M.A., Kremsner, J.M. and Kappe, C.O. (2008) Nonthermal Microwave Effects Revisited: On the Importance of Internal Temperature Monitoring and Agitation in Microwave Chemistry. Journal of Organic Chemistry, 73, 36-47.

https://doi.org/10.1021/jo7022697

[23] De la Hoz, A. and Loupy, A. (2013) Microwaves in Organic Synthesis. Wiley-VCH, Weinheim, Germany, Vol. 1 \& 2 .

[24] Corsaro, A., Chiacchio, U., Pistara, V. and Romeo, G. (2004) Microwave-Assisted Chemistry of Carbohydrates. Current Organic Chemistry, 8, 511-538. https://doi.org/10.2174/1385272043485828

[25] Richard, A. and Paquot, M. (2012) Conversion of Carbohydrates under Microwave Heating. In: Chang, C.-F., Ed., Carbohydrates-Comprehensive Studies on Glycobiology and Glycotechnology, IntechOpen, London, 22-36.

[26] Tsubaki, S. and Azuma, J. (2011) Application of Microwave Technology for Utilization of Recalcitrant Biomass. In: Grundas, S., Ed., Advances in Induction and Microwave Heating of Mineral and organic Materials, IntechOpen, London, 697-722. https://doi.org/10.5772/14040

[27] Román-Leshkov, Y., Chheda, J.N. and Dumesic, J.A. (2006) Phase Modifiers Promote Efficient Production of Hydroxymethylfurfural from Fructose. Science, 312, 1933-1937. https://doi.org/10.1126/science.1126337

[28] Tsubaki, S., Onda, A., Yanagisawa, K. and Azuma, J. (2012) Microwave-Assisted Hydrothermal Hydrolysis of Maltose with Addition of Microwave Absorbing Agents. Procedia Chemistry, 4, 288-293. https://doi.org/10.1016/j.proche.2012.06.040

[29] Tsubaki, S., Oono, K., Onda, A., Yanagisawa, K. and Azuma, J. (2013) Comparative Decomposition Kinetics of Neutral Monosaccharides by Microwave and Induction Heating Treatments. Carbohydrate Research, 375, 1-4.

https://doi.org/10.1016/j.carres.2013.04.013

[30] Möller, M., Harnisch, F. and Schröder, U. (2012) Microwave-Assisted Hydrothermal Degradation of Fructose and Glucose in Subcritical Water. Biomass and Bioenergy, 39, 389-398. https://doi.org/10.1016/j.biombioe.2012.01.036

[31] Angyal, S.J. (2001) The Lobry de Bruyn-Alberda van Ekenstein Transformation and Related Reactions. In: Stutz, E.A., Ed., Glycoscience: Epimerization, Isomerization and Rearrangement Reactions of Carbohydrates, Springer-Verlag, Berlin, Vol. 215, 1-14. https://doi.org/10.1007/3-540-44422-X_1

[32] Pagnotta, M., Pooley, C.L.F., Gurland, B. and Choi, M. (1993) Microwave Activation of the Mutarotation of $\alpha$-D-Glucose: An Example of an Intrinsic Microwave Effect. Journal of Physical Organic Chemistry, 6, 407-411. https://doi.org/10.1002/poc.610060705 
[33] Munegumi, T. and Goto, A. (2014) Microwave-Assisted Isomerization of Glucose to Fructose. Research Journal of Pharmaceutical Biological Chemical Science, 5, 206-212. https://www.rjpbcs.com/2014_5.3.html

[34] Capuano, E. and Vincenzo, F. (2011) Acrylamide and 5-Hydroxymethylfurfural (HMF): A Review on Metabolism, Toxicity, Occurrence in Food and Mitigation Strategies. LWT-Food Science and Technology, 44, 793-810. https://doi.org/10.1016/j.lwt.2010.11.002

[35] Zirbes, L., Nguyen, B.K., de Graaf, D.C., Meulenaer, B.D., Reybroeck, W., Haubruge, E. and Saegerman, C. (2013) Hydroxymethylfurfural: A Possible Emergent Cause of Honey Bee Mortality? Journal of Agricultural and Food Chemistry, 61, 11865-11870. https://doi.org/10.1021/jf403280n 